О.Н. Бушмина, А.Л. Локтионов, С.А. Долгарева, А.И. Конопля
Фармакологическая коррекция метаболических нарушений при экспериментальном остром панкреатите на фоне хронической алкогольной интоксикации

ФГБОУ ВО «Курский государственный медицинский университет», ул. К. Маркса, д. 3, г. Курск, 305041, Российская Федерация Автор для переписки: О.Н. Бушиина (o.buschmina@yandex.ru)

Информация для цитирования: Фармакологическая коррекция метаболических нарушений при экспериментальном остром панкреатите на фоне хронической алкогольной интоксикации / О.Н. Бушмина [и др.] // Научные результаты биомедицинских исследований. 2018. Т. 4, N 4. С. 35-51. [Bushmina ON, Loktionov AL, Dolgareva SA, et al. Pharmacological correction of metabolic disturbances in experimental acute pancreatitis on the background of chronic alcohol intoxication. Research Results in Biomedicine. 2018;4(4):35-51 (In Russian)]. DOI: 10.18413/2313-8955-2018-4-4-0-5

\title{
Аннотация
}

Актуальность: Острый панкреатит занимает третье место среди всех острых хирургических заболеваний органов брюшной полости и представляет собой одну из важных нерешённых проблем в неотложной хирургии. Цель исследования: установить особенности иммунометаболических изменений при остром панкреатите при кратковременной и хронической интоксикации этанолом, разработать способы фармакологической коррекции выявленных нарушений. Материалы и методы: Эксперимент включил 377 половозрелых крыс линии Wistar. Алкогольную интоксикацию моделировали путем интрагастрального введения 20\% раствора спирта этилового в дозе 3 мл/кг через 24 часа в течение 5 суток. При хронической алкогольной интоксикации (ХАИ) спирт давали животным в течение 30 суток (ХАИ-30) или 60 суток (ХАИ-60). Моделирование острого панкреатита осуществляли по Wang R.N. в модификации C.A. Алехина (2006) путем лигирования протока левой и правой доли панкреаса и стимуляцией прозерином троекратно через каждые 60 мин. Результаты: Кратковременная интоксикация в течение 5 суток спиртом этиловым у крыс приводит к незначительным метаболическим изменениям реактивного характера, 30-дневное, а еще в большей степени, 60-дневное его введение, - к развитию токсического поражения печени, окислительному стрессу, дисбалансу формирования адаптивного и врожденного иммунного ответа, изменениям функционально-метаболической активности циркулирующих эритроцитов. В условиях острого деструктивного панкреатита (ОДП) на фоне 30-дневной интоксикации спиртом этиловым оказались нарушенными 97,1\% исследованных лабораторных показателей. Введение фосфоглива, гепона и гипоксена нормализовало $12,1 \%$ измененных 
метаболических показателей, корректировало 60,6\% и не изменяло 27,3\%. Комбинация гептрала, глутоксима и мексидола оказалась более эффективной, поскольку корригировала $42,4 \%$ и нормализовала $57,8 \%$ исследованных параметров иммунометаболического статуса. В условиях интоксикации этанолом в течение 60 дней оказались нарушенными 100\% лабораторных показателей. Введение фосфоглива, гипоксена и гепона корректировало из них $38,2 \%$ и приводило к норме 11,8\%. Сочетание гептрала, глутоксима и мексидола корригировало $67,6 \%$ и показателей. Заключение: При оценке собственных корригирующих эффектов при ОДП на фоне 30- и 60-дневной алкогольной интоксикации сочетание гептрала, глутоксима и мексидола (84 и 37 баллов соответственно) оказалась более предпочтительней чем фосфоглива, гипоксена и гепона (46 и 15 баллов соответственно).

Ключевые слова: алкогольная интоксикация; метаболические нарушения; фармакологическая коррекция

\title{
Olga N. Bushmina, Alexey L. Loktionov, Svetlana A. Dolgareva, Alexandr I. Konoplya
}

\section{Pharmacological correction of metabolic disturbances in experimental acute pancreatitis on the background of chronic alcohol intoxication}

\author{
Kursk State Medical University, \\ 3 K. Marx St., Kursk, 305041, Russia \\ Corresponding author: Olga N. Bushmina (o.buschmina@yandex.ru)
}

\begin{abstract}
Background: Acute pancreatitis ranks third among all acute surgical diseases of the abdominal cavity and is one of the important unresolved problems in emergency surgery. The aim of the study: to establish the features of immunometabolic changes in acute pancreatitis with short-term and chronic ethanol intoxication, to develop ways of pharmacological correction of the revealed disorders. Materials and methods: The studies were conducted on 377 healthy sexually mature Wistar rats. Alcoholic intoxication was modeled by intragastric injection of $20 \%$ ethanol solution at a dose of $3 \mathrm{ml} / \mathrm{kg}$ after 24 hours for 5 days. In chronic alcohol intoxication (CAI) ethanol was injected for 30 or 60 days (CAI-30, CAI-60). Acute pancreatitis was modeled (R.N. Wang) in the modification of A.S. Alekhin (2006) by ligating the duct of the left and right lobes of the pancreas and stimulating the prozerin three times every 60 min. Results: Short-term intoxication (5 days) with ethanol causes minor metabolic changes of reactive nature, 30-day, more than 60-day injection, leads to the development of toxic liver damage, oxidative stress, imbalance in the formation of adaptive and innate immune response, disorders of functional and metabolic activity of circulating red blood cells. In the conditions of acute destructive pancreatitis (ADP) on the background of 30-day alcohol intoxication $97.1 \%$ of the laboratory parameters were violated. Injection of Phosphogliv, Hypoxene and Hepon normalized 12.1\% of altered metabolic parameters, corrected $-60.6 \%$ and did not affect $-27.3 \%$. The combination of Heptral, Glutoxim and Mexidol was more effective because it corrected $42.4 \%$ and normalized $57.8 \%$ of the studied parameters of immunometabolic
\end{abstract}


status. In the conditions of ethanol intoxication within 60 days in acute pancreatitis, $100 \%$ of laboratory parameters were violated. Injection of Phosphogliv, Hypoxene and Hepon corrected $38.2 \%$ and normalized $11.8 \%$. The combination of Heptral, Glutoxim and Mexidol corrected $67.6 \%$ and normalized $17.6 \%$ of the studied parameters. Conclusion: The combination of Heptral, Glutoxim and Mexidol (84 and 37 points, respectively) was more preferable than Phosphogliv, Hypoxene and Hepon (46 and 15 points, respectively) in the assessment of their own corrective effects in EDP on the background of 30 - and 60-day alcohol intoxication.

Keywords: alcohol intoxication; metabolic disorders; pharmacological correction

Введение. Интоксикация этанолом, хронический алкоголизм и связанные с ними заболевания являются важнейшими медико-социальными проблемами. Панкреатобилиарная система наиболее чувствительна к действию алкоголя, который является одним из ведущих этиологических факторов в развитии ее заболеваний $[1,2]$.

В различных исследованиях установлено, что длительный прием алкоголя и/или возникновение острого панкреатита приводит к супрессии защитных иммунных механизмов, снижению способности организма противостоять микробной агрессии, повышению возникновения гнойнонекротических осложнений, резкому замедлению процессов репаративной регенерации $[3,4,5,6]$.

Одними из ведущих патогенетических механизмов развития болезней, основу которых составляет воспаление, является оксидантный стресс, избыточное накопление активных форм кислорода, снижение факторов антиоксидантной защиты. При деструктивных формах острого панкреатита на фоне окислительного стресса темпы восстановления недостаточны, вследствие этого в организме накапливаются поврежденные молекулы, изменяющие состояние регуляторных систем, в том числе иммунной $[7,8,9]$.

В регуляции функции иммунной системы участвуют эритроциты, среди функций которых, помимо газотранспортной, является обеспечение иммунного гомеостаза, в том числе и при болезнях печени и поджелудочной железы $[4,8,10]$.
При возникновении острого панкреатита наличие фоновых заболеваний, таких как, хроническая алкогольная интоксикация, сахарный диабет всегда оказывает отрицательное влияние на течение основного заболевания, что обосновывает многокомпонентную фармакологическую коррекцию нарушений в сочетании с хирургическими методами лечения $[11,12,13]$.

Поджелудочная железа, головной мозг, печень, иммунная система и эритроциты являются основными мишенями воздействия этанола или метаболитов, появляющихся в крови при остром панкреатите, после чего выявляются значительные нарушения соответствующих параметров гомеостаза. Наличие острого панкреатита или длительная интоксикация этанолом изолированно, либо совместно индуцируют развитие вторичного иммунодефицитного состояния, активацию перекисного окисления липидов, изменение структурнофункциональных параметров эритроцитов, дезрегуляцию метаболизма, нарушение регенерации тканей $[14,15]$.

В настоящее время вопросы о состоянии свободно-радикального окисления, факторов антиоксидантной защиты, иммунного гомеостаза при длительной алкогольной интоксикации, метаболических и иммунных нарушений при остром панкреатите на фоне хронического злоупотребления алкоголем требуют дальнейших экспериментальных и клинических исследований.

В связи с изложенным, очевидна целесообразность дальнейшего изучения патогенетических проблем острого панкреатита на фоне хронической алкогольной интоксика- 
ции и клинического изучения небилиарного (алкогольного) панкреатита, что даст основу для разработки и внедрения новых методов фармакологической реабилитации. При этом, основу фармакологической коррекции нарушений гомеостаза при остром панкреатите с предшествующим алкогольным анамнезом, несомненно, должны играть иммунотропные и гепатопротекторные препараты $[2,4,5,16,17]$.

Цель исследования - установить особенности иммунометаболических изменений при остром панкреатите при кратковременной и хронической интоксикации этанолом, разработать способы фармакологической коррекции выявленных нарушений.

Материалы и методы исследования. Эксперименты проводились на 377 половозрелых крысах линии Wistar массой от 150 до 200 г. Исследования проходили с 8.00 до 12.00 , содержание и выведение животных из эксперимента проводили с соблюдением принципов, изложенных в Конвенции по защите позвоночных животных, используемых для экспериментальных и других целей (г. Страсбург, Франция, 1986), и согласно правилам лабораторной практики РФ (приказ МЗ РФ № 267 от 19.06.2003 г.).

В эксперимент вошли группы животных: 1 группа - здоровые крысы (12 шт.), 2 группа - получавшие этанол 5 дней (11 шт.), 3 группа - модель ОДП при введении этанола в течение 5 дней (11 шт.), 4 группа этанол, 30 дней (12 шт.), 5 группа - ОДП на фоне введения этанола в течение 30 дней (12 шт.), 6 группа - ОДП на фоне введения этанола в течение 30 дней и гепона, гипоксена и фосфоглива (11 шт.), 7 группа ОДП на фоне введения этанола в течение 30 дней и глутоксима, мексидола и гептрала (12 шт.), 8 группа - этанол, 60 дней (12 шт.), 9 группа - ОДП на фоне введения этанола в течение 60 дней (12 шт.), 10 группа - ОДП на фоне введения этанола в течение 60 дней и гепона, гипоксена и фосфоглива (12 шт.), 11 группа - ОДП на фоне введения этанола в течение 60 дней и глутоксима, мексидола и гептрала (11 шт.).

Алкогольную интоксикацию моделировали путем интрагастрального введения $20 \%$ раствора этилового спирта в дозе 3 мл/кг каждые 24 часа в течение 5 суток. При ХАИ спирт этиловый вводили в течение 30 или 60 суток.

Модель ОДП воспроизводили по Wang R.N. в модификации Алехина C.A. (2006) путем лигирования протока левой и правой доли панкреаса и прозериновой стимуляцией троекратно через каждые 60 мин. На первые сутки после моделирования патологии при гистологическом исследовании определяется отек панкреаса, выражены очаги центролобулярных некрозов с умеренно выраженной нейтрофильной инфильтрацией некротических очагов и стромы поджелудочной железы. Моделирование ОДП производили сразу с кратковременным получением спирта этилового или на 25-е и 55-е сутки после его длительного введения.

Для гистологического подтверждения формирования моделируемых патологических изменений и оценки эффективности препаратов проведено гистологическое исследование печени и поджелудочной железы. Для этого кусочки исследуемых органов фиксировали в $10 \%$ формалине на $0,1 \mathrm{M}$ фосфатном буфере $(\mathrm{pH}=7,2)$ и заливали в парафин. Парафиновые срезы толщиной 7-10 мкм окрашивали гематоксилином Рего и эозином.

Дозировки, способы и кратность введения фармакологических препаратов представлен в таблице 1 . Расчет доз фармакологических агентов для введения лабораторным крысам производили, используя коэффициенты пересчета доз, в зависимости от массы тела животного, либо эмпирически, основываясь на $\mathrm{LD}_{50}$. 
Таблица 1

Дозы, пути и кратность введения препаратов крысам с моделью острого деструктивного панкреатита

Table 1

Dosage, methods and frequency of drug injection to rats with the experimental model of acute destructive pancreatitis

\begin{tabular}{|c|c|c|c|c|}
\hline \multirow[b]{2}{*}{ Препарат } & \multirow[b]{2}{*}{ Путь введения } & \multirow[b]{2}{*}{$\begin{array}{l}\text { Разо- } \\
\text { вая } \\
\text { доза, } \\
\text { мг/кг }\end{array}$} & \multicolumn{2}{|c|}{ Схема введения } \\
\hline & & & $\begin{array}{c}\text { Коли } \\
\text { чест- } \\
\text { во } \\
\text { вве- } \\
\text { де- } \\
\text { ний }\end{array}$ & $\begin{array}{c}\text { Интер- } \\
\text { вал } \\
\text { между } \\
\text { введени- } \\
\text { ями, ч }\end{array}$ \\
\hline $\begin{array}{l}\text { Гепон (Thr-Glu-Lys-Lys-Arg-Arg-Glu-Thr- } \\
\text { Val-Glu-Arg-Glu-Lys-Glu) (OOO "ИММA- } \\
\text { ФАРМА", РФ) }\end{array}$ & перорально & 5 & 14 & 24 \\
\hline $\begin{array}{l}\text { Гипоксен (поли-(2,5-дигидроксифенилен)- } \\
\text { 4-тиосульфонат натрия) (ООО "ОЛИФЕН", } \\
\text { РФ) }\end{array}$ & $\begin{array}{l}\text { перорально в } 1 \% \\
\text { крахмальной } \\
\text { суспензии }\end{array}$ & 750 & 14 & 24 \\
\hline $\begin{array}{l}\text { Фосфоглив (фосфотидинхо- } \\
\text { лин+тринатриевая соль глицирридновой } \\
\text { кислоты) (ОАО "Фармстандарт-Уфимский } \\
\text { витаминный завод", РФ) }\end{array}$ & $\begin{array}{l}\text { перорально в } 1 \% \\
\text { крахмальной } \\
\text { суспензии }\end{array}$ & 800 & 14 & 24 \\
\hline $\begin{array}{l}\text { Глутоксим (бис-(гамма-L-глутамил)-L- } \\
\text { цистеинил-бис-глицин динатриевая соль) } \\
\text { (ЗАО "ФАРМА ВАМ", РФ) }\end{array}$ & внутримышечно & 20 & 5 & 24 \\
\hline $\begin{array}{l}\text { Мексидол (2-этил-6-метил-3- } \\
\text { гидроксипиридина сукцинат) (ЗАО «АЛ- } \\
\text { СИ-Фарма», РФ) }\end{array}$ & внутрибрюшинно & 50 & 14 & 24 \\
\hline $\begin{array}{l}\text { Гептрал (S-Аденозил-L-метионина 1,4- } \\
\text { бутандисульфонат) (Хоспира С.п.А., Виа } \\
\text { Фоссе Ардеатине, 2-20060 Лискате (МИ), } \\
\text { Италия) }\end{array}$ & внутрибрюшинно & 760 & 5 & 24 \\
\hline
\end{tabular}

Выведение животных осуществляли через 24 часа после последнего введения спирта этилового или спирта и препаратов.

Забор крови у крыс осуществлялся под общей анестезией, путем внутрисердечной инъекции. Плазму получали из гепаринизированной крови путем центрифугирования в течение 5 мин при 400g. При оценке функционального состояния гепатоцитов в плазме определяли активность энзимов: аспартат- и аланинаминотрансфераз (АСТ, АЛТ), щелочной фосфатазы (ЩФ), гаммаглутаминтранспептидазы (ГГТ), а также содержание билирубина стандартными методами клинической биохимии на автоматическом биохимическом анализаторе «COBAS c311»
(Roche, Германия) реагентами Analyticon ${ }^{\circledR}$ Biotechnologies AG (Германия). Протромбиновый индекс (ПТИ) определяли клоттинговым методом на полуавтоматическом анализаторе показателей гемостаза «Start 4» (Stago, Франция) с применением реагентов «Human» (Германия). Концентрацию фибриногена определяли клоттинговым методом по Клаусс на полуавтоматическом анализаторе показателей гемостаза «Start 4» (Stago, Франция) с применением реагентов Diagnostica Stago (Франция).

Интенсивность протекания процессов перекисного окисления липидов (ПОЛ) оценивали по уровню в плазме ацилгидроперекисей (АГП) и малонового диальдегида 
(МДА). При оценке состояния антиоксидантной системы определяли активность супероксиддисмутазы (СОД) «Bender Medsystems» (Австрия) и каталазы «Саyman Chemical» (США) с использованием готовых коммерческих наборов. Общую антиокислительную активность (ОАА), определяли методом, базирующимся на ингибировании аскорбат- и ферроиндуцированного окисления твина-80 до МДА. Уровень конечных метаболитов $\mathrm{NO}\left(\mathrm{CM}_{\mathrm{ON}}\right)$ по реакции Грисса с использованием набора для твердофазного иммуноферментного анализа (ИФА) фирмы «R\&D» (Англия). Регистрация всех результатов ИФА проводилась с применением микропланшетного фотометра «Sunrise», Tecan (Австрия).

Для формирования гуморального иммунного ответа (ГИО) антиген эритроциты барана вводили интраперитонеально один раз. ГИО оценивали на 5 день после иммунизации при определении в селезенке числа антителообразующих клеток (Мальберг К., Зигль Э., 1987). Гиперчувствительность замедленного типа (ГЗТ) моделировали интраперитонеальным введением $10^{8}$ эритроцитов барана в 0,5 мл 0,15 моль/л раствора хлористого натрия. Через 4 дня в подушечку стопы правой лапки крысы вводили $10^{6}$ ЭБ в 0,1 мл 0,15 моль/л раствора хлористого натрия (разрешающая доза). Спустя сутки выделяли регионарный и контрлатеральный подколенный лимфатические узлы. О выраженности ГЗТ судили по разнице масс регионарного и контрлатерального лимфоузлов и по разнице в числе кариоцитов.

Выделение нейтрофилов из полученной крови проводили на градиенте плотности фиколл-урографина $(\rho=1,078)$. Их фагоцитарную активность определяли по стандартной методике, оценивая фагоцитарный индекс (ФИ), фагоцитарное число (ФЧ) и индекс активности фагоцитоза (ИАФ). Активность кислород-зависимых систем нейтрофилов оценивали спектрофотометрически по НСТ-тесту, спонтанного и стимулированного зимозаном (НСТ-ст. н/3),
(НСТ-ст. о/з), с расчетом функционального резерва [18].

Подсчет общего числа эритроцитов, содержание гемоглобина в полученной крови проводили на автоматическом гематологическом анализаторе «XP 300» (Sysmex, Германия). Эритроциты получали из гепаринизированной крови, после ее центрифугирования при $400 \mathrm{~g}$ и отделения плазмы крови.

Определяли общую сорбционную способность эритроцитов, обусловленную наружной архитектоникой мембраны и сорбционную емкость гликокаликса эритроцитов ${ }^{1}$.

Статистическая обработка данных проводили по критериям вариационностатистического анализа с вычислением средних величин (M), ошибки средней арифметической (m) с помощью программы Microsoft Excel, 2010. Существенность различий оценивали по Т-критерию. Статистически достоверными считали различия с $\mathrm{p}<0,05$. Степень расстройств лабораторных показателей, их изменения под влиянием фармакологических средств, рейтинговый алгоритм лабораторных показателей, сумму степеней коррекции иммунометаболических показателей определяли по формулам А.М. Земскова.

Результаты и их обсуждение. У крыс с 5-кратным введением спирта этилового обнаружено только повышение активности АСТ и коэффициента де Ритиса за счет этого энзима. У животных с ОДП при 5-дневной алкогольной интоксикации выявлено увеличение содержания билирубина, активности АСТ, АЛТ, ЩФ, ГГТ и коэффициента де Ритиса, понижение уровня фибриногена, повышение ПТИ (таблица 2).

\footnotetext{
1 Примечание. Определение иммунологических и биохимических показателей проведено в лаборатории иммуноферментного анализа НИИ экологической медицины Курского государственного медицинского университета и клинической лаборатории МУЗ ГКБ № 4 г. Курска, за что выражаем сотрудникам соответствующих подразделений глубокую признательность.
} 
Таблиияа 2

\section{Функциональная активность гепатоцитов при остром деструктивном панкреатите на фоне кратковременного введения этанола (M+m)}

Table 2

Functional activity of hepatocytes in acute destructive pancreatitis in short-term injection of ethanol $(\mathrm{M}+\mathrm{m})$

\begin{tabular}{|c|c|c|c|c|c|}
\hline \multirow[b]{2}{*}{ № п\п } & \multirow[b]{2}{*}{ Показатели } & \multirow[b]{2}{*}{$\begin{array}{c}\text { Единицы } \\
\text { измерения }\end{array}$} & 1 & 2 & 3 \\
\hline & & & Контроль & $\begin{array}{c}\text { Этанол - } \\
5 \text { дней }\end{array}$ & $\begin{array}{c}\text { ОДП+этанол } \\
5 \text { дней }\end{array}$ \\
\hline 1 & $\mathrm{ACT}$ & $\mathrm{E} /$ Л & $21,3 \pm 1,6$ & $26,1 \pm 2,1^{* 1}$ & $33,8 \pm 3,2^{* 1,2}$ \\
\hline 2 & АЛТ & $\mathrm{E} /$ л & $20,1 \pm 2,4$ & $19,6 \pm 1,4$ & $27,7 \pm 2,2^{* 1,2}$ \\
\hline 3 & Коэффициент де Ритиса & АСТ/АЛТ & $1,06 \pm 0,02$ & $1,3 \pm 0,05^{* 1}$ & $1,2 \pm 0,06^{* 1}$ \\
\hline 4 & ЩФ & $\mathrm{E} /$ Л & $249,2 \pm 18,8$ & $261,4 \pm 12,5$ & $345,8 \pm 10,4^{* 1,2}$ \\
\hline 5 & ГГТ & $\mathrm{E} /$ Л & $4,8 \pm 0,22$ & $5,1 \pm 1,0$ & $7,1 \pm 1,4^{* 1,2}$ \\
\hline 6 & Коэффициент ГГТ/АСТ & ГГТ/ACТ & $0,23 \pm 0,01$ & $0,2 \pm 0,02$ & $0,21 \pm 0,01$ \\
\hline 7 & Билирубин & мкмоль/л & $5,74 \pm 1,2$ & $5,9 \pm 0,9$ & $7,7 \pm 1,4^{* 1,2}$ \\
\hline 8 & ПТИ & $\%$ & $60,1 \pm 1,6$ & $62,7 \pm 2,4$ & $70,1 \pm 3,1^{* 1,2}$ \\
\hline 9 & Фибриноген & Г/л & $3,12 \pm 0,09$ & $3,3 \pm 0,2$ & $2,84 \pm 0,1^{* 1,2}$ \\
\hline
\end{tabular}

Примечание: на этой и последующих таблицах «*» отмечены статистически достоверные отличия средних арифметических $(\mathrm{p}=0,05)$; цифры рядом с «*»- по отношению к показателям какой экспериментальной группы даны эти различия.

Note: on this and subsequent tables $\langle * »$ there are statistically significant differences in arithmetic means $(\mathrm{p}=0.05)$; the numbers next to $\left\langle^{*}\right\rangle-$ in relation to the indicators of which experimental group these differences are given.

Введение этанола в течение 30 дней повысило ПТИ, активность АСТ, АЛТ, ГГТ, концентрацию билирубина, снизило содержание фибриногена и соотношение АСТ/АЛТ (рис. 1).

У животных с ОДП с 30-дневной интоксикацией этиловым спиртом было отмечено большее увеличение активности АЛТ, билирубина, ЩФ и ГГТ, уменьшение коэффициента де Ритиса, увеличение ГГТ/АСТ при сохранении на одном уровне синдрома недостаточности синтетических процессов (снижение уровня фибриногена) и активация свертывающей системы крови (повышение ПТИ) (рис. 1)

60-дневная интоксикация спиртом по сравнению с 30-дневной больше повышала активность АСТ, ЩФ, ГГТ, коэффициенты де Ритиса и ГГТ/АСТ, содержание билирубина. В тоже время при ХАИ-60 нормализовалась концентрация фибриногена и снижалось ПТИ, но не значений контроля (рис. 1). У крыс с ОДП при ХАИ-60 по сравнению с тем же временным введением только спирта или ОДП при ХАИ-30, повышалась активность АЛТ, АСТ, ЩФ, снижались коэффициенты ферментативной активности и содержание фибриногена (рис. 1).

При ОДП в условиях ХАИ-60 установлено, что сочетание гепона, гипоксена и фосфоглива нормализовало ПТИ и уровень фибриногена, корригировало, но не до показателей здоровых животных, активность АСТ, АЛТ, ЩФ, ГГТ и концентрацию билирубина (рис. 1).

Композиция глутоксима, мексидола и гептрала, по сравнению с предыдущим сочетанием препаратов, дополнительно корригировало активность ЩФ, ГГТ и коэффициент ГГТ/АСТ (рис. 1). Полученные результаты позволяют заключить, что у лабораторных крыс с ОДП при алкогольной интоксикации наблюдается развитие основных биохимических изменений поражения печени. 

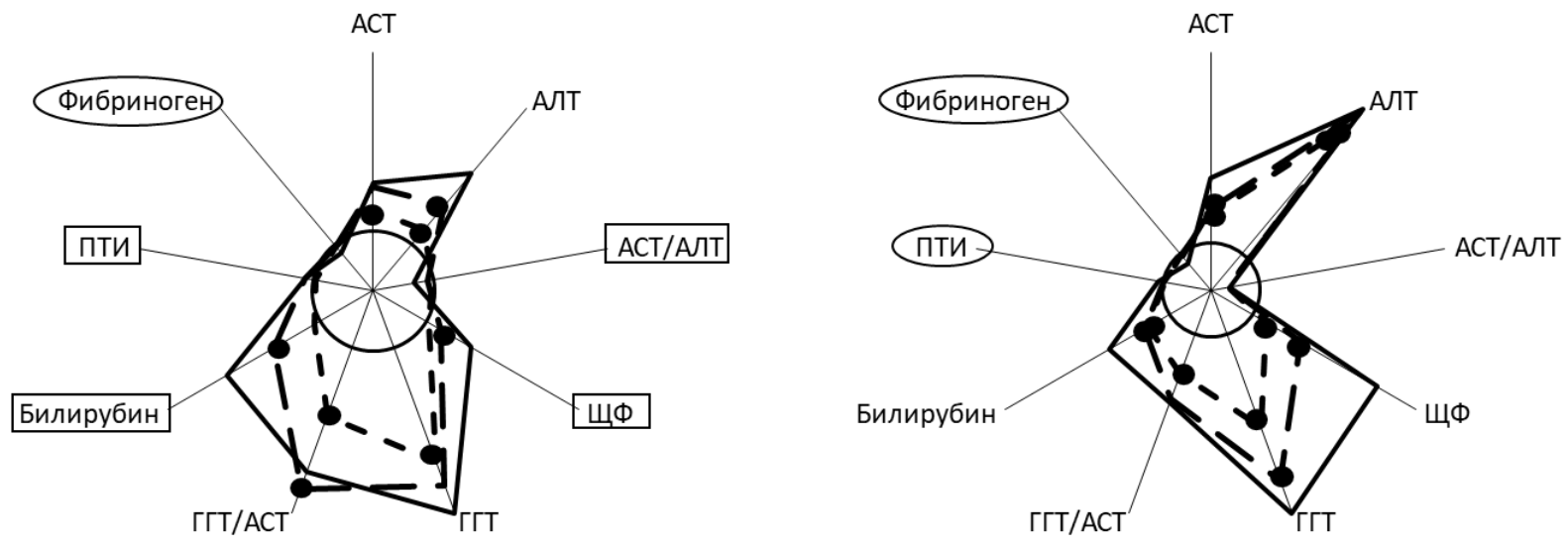

\section{Обозначения:}

1 - радиус окружности показатели интактных животных;

2 - — показатели крыс с 30- и 60-дневной ХАИ + ОДП;

3 - _ - - показатели крыс с 30- и 60-дневной ХАИ + ОДП + гепон, гипоксен и фосфоглив;

4 - _ - - - показатели крыс с 30- и 60-дневной ХАИ + ОДП + глутоксим, мексидол и гептрал;

5 - $\quad$ - скорригированный показатель $(\mathrm{p}<0,05)$;

$6-\bigcirc-$ показатель, нормализованный сочетанием гепон, гипоксен, фосфоглив $(\mathrm{p}>0,05)$;

7 - $\square-$ показатель, нормализованный сочетанием глутоксим, мексидол, гептрал $(\mathrm{p}>0,05)$.

Legend:

1 - radius of a circle indicators of intact animals;

$2--$ indicators of rats with 30- and 60-day HAI + CCT;

$3-z_{-}-$indicators of rats with 30- and 60-day HAI + ODP + gepon, hypoxen and phosphogliv;

4 - - - - - indicators of rats with 30- and 60-day HAI + ODP + glutoxim, mexidol and heptral;

$5-\quad-$ corrected indicator $(\mathrm{p}<0.05)$;

$6-\bigodot$ - indicator, normalized by the combination of gepon, hypoxen, phosphoglive ( $\mathrm{p}>0.05)$;

7 - $\square$-indicator normalized by the combination of glutoxim, mexidol, heptral ( $>>0.05$ ).

Рис. 1. Фармакологическая коррекция нарушений функциональной активности гепатоцитов при моделировании ОДП на фоне 30- и 60-дневного введения спирта этилового

Fig. 1. Pharmacological correction of impaired functional activity of hepatocytes in the simulation of acute destructive pancreatitis on the background of 30- and 60-day injection of ethyl alcohol

В данных условиях применение фармакологических агентов с иммуномодулирующим, антиоксидантным и мембранопротекторным действием оказалось эффективным.

Кратковременное поступление этанола снижает фагоцитарную активность (снижение ФП, ФЧ, ИАФ) при одновременном повышении кислородзависимого метаболизма нейтрофилов периферической крови в НСТ- тестах спонтанном и стимулированном неопсонизированным зимозаном. По сравнению со здоровыми крысами, уменьшались коэффициент активности на неопсонизированный зимозан (Кан) и коэффициент активности на опсонизированный зимозан (KAo).

У крыс с ОДП при кратковременной интоксикации этанолом еще больше умень- 
шалась фагоцитарная активность и увеличивалась кислородзависимая метаболическая гранулоцитарная активность. А также снижались все резервы функциональной активности клеток.

Симуляция хронической интоксикации путем 30-дневного интрагастрального введения этанола в одинаковой степени по сравнению с группой, получавшей токсический агент в течение 60 суток, угнетало фагоцитарную и стимулировало кислородзависимую активность нейтрофилов перифери- ческой крови. Показатель НСТ-ст. о/з в этих экспериментальных группах не отличался от значений группы контроля (табл. 3).

При ОДП и ХАИ-30, еще более при ХАИ-60, наблюдалось явное снижение ФП, ФЧ, ИАФ и увеличение НСТ-ст. о/3 и н/3, НСТ-сп. Резервы кислородзависимой фагоцитарной активности у крыс (КАо, КАн и КО), подвергаемых хронической интоксикации алкоголем, в том числе в комбинации с острым панкреатитом, оказались сниженными (табл. 3).

Таблица 3

\section{Функционально-метаболическая активность циркулирующих нейтрофилов при моделировании острого деструктивного панкреатита при 30- и 60-дневной хронической интоксикации этанолом (M+m)}

Table 3

Functional metabolic activity of circulating neutrophils in the simulation of acute destructive pancreatitis in 30- and 60-day chronic toxicity with ethanol $(\mathrm{M}+\mathrm{m})$

\begin{tabular}{|c|c|c|c|c|c|c|}
\hline \multirow[b]{2}{*}{$\begin{array}{l}\text { № } \\
\text { п\п }\end{array}$} & \multirow[b]{2}{*}{ Показатели } & \multirow[b]{2}{*}{$\begin{array}{l}\text { Единицы } \\
\text { измерения }\end{array}$} & 1 & 2 & 3 & 4 \\
\hline & & & $\begin{array}{l}\text { Кон- } \\
\text { троль }\end{array}$ & $\begin{array}{c}\text { ОДП + эта- } \\
\text { нол }\end{array}$ & $\begin{array}{l}\text { Гепон + ги- } \\
\text { поксен } \\
\text { фосфоглив }\end{array}$ & $\begin{array}{l}\text { Глутоксим+ мек- } \\
\text { сидол+гептрал }\end{array}$ \\
\hline \multicolumn{7}{|c|}{ 30-дневная хроническая интоксикация этанолом и экспериментальный ОДП } \\
\hline 1 & $\Phi Ч$ & абс. & $2,8 \pm 0,1$ & $2,2 \pm 0,08^{* 1}$ & $2,48 \pm 0,08^{* 1,2}$ & $2,9 \pm 0,17^{* 2,3}$ \\
\hline 2 & $\Phi \Pi$ & $\%$ & $77,2 \pm 1,6$ & $37,3 \pm 2,2^{*}$ & $47,0 \pm 4,08^{* 1,2}$ & $66,3 \pm 3,4^{* 1-3}$ \\
\hline 3 & ИАФ & - & $2,2 \pm 0,09$ & $0,8 \pm 0,08^{* 1}$ & $1,57 \pm 0,1^{* 1,2}$ & $1,91 \pm 0,03^{* 1-3}$ \\
\hline 4 & НСТ-сп. & $\mathrm{mOD}$ & $0,8 \pm 0,02$ & $1,9 \pm 0,09^{* 1}$ & $1,67 \pm 0,09^{* 1,2}$ & $1,05 \pm 0,05^{* 1-3}$ \\
\hline 5 & НСТ-ст. н/3 & $\mathrm{mOD}$ & $1,3 \pm 0,02$ & $2,0 \pm 0,15^{* 1}$ & $1,72 \pm 0,05^{* 1,2}$ & $1,32 \pm 0,03^{* 2,3}$ \\
\hline 6 & НСТ-ст. о/3 & $\mathrm{mOD}$ & $1,6 \pm 0,03$ & $2,2 \pm 0,12^{* 1}$ & $1,77 \pm 0,08^{* 1,2}$ & $1,58 \pm 0,03^{* 2,3}$ \\
\hline 7 & $\mathrm{KO}$ & - & $1,2 \pm 0,04$ & $1,1 \pm 0,02^{* 1}$ & $1,05 \pm 0,02^{* 1,2}$ & $1,27 \pm 0,04^{* 2,3}$ \\
\hline 8 & KAo & - & $2,0 \pm 0,06$ & $1,07 \pm 0,09^{* 1}$ & $1,033 \pm 0,08^{* 1}$ & $1,62 \pm 0,04^{* 1-3}$ \\
\hline 9 & КАн & - & $1,6 \pm 0,05$ & $1,15 \pm 0,09^{* 1}$ & $1,08 \pm 0,04^{* 1,2}$ & $1,56 \pm 0,07^{* 2,3}$ \\
\hline \multicolumn{7}{|c|}{ 60-дневная хроническая интоксикация этанолом и экспериментальный ОДП } \\
\hline 1 & HCT-сп. & $\mathrm{mOD}$ & $0,8 \pm 0,02$ & $1,95 \pm 0,03^{* 1}$ & $2,0 \pm 0,02^{* 1}$ & $1,7 \pm 0,06^{* 1-3}$ \\
\hline 2 & НСТ-ст. н/3 & $\mathrm{mOD}$ & $1,3 \pm 0,02$ & $2,2 \pm 0,06^{* 1}$ & $2,1 \pm 0,05^{* 1}$ & $1,8 \pm 0,02^{* 1-3}$ \\
\hline 3 & НСТ-ст. о/3 & $\mathrm{mOD}$ & $1,6 \pm 0,03$ & $2,1 \pm 0,2^{* 1}$ & $2,24 \pm 0,1^{* 1}$ & $1,12 \pm 0,05^{* 1-3}$ \\
\hline 4 & $\mathrm{KO}$ & - & $1,2 \pm 0,04$ & $0,96 \pm 0,07^{* 1}$ & $1,07 \pm 0,12^{* 1}$ & $0,86 \pm 0,09^{* 1}$ \\
\hline 5 & KAo & - & $2,0 \pm 0,06$ & $1,14 \pm 0,02^{* 1}$ & $1,12 \pm 0,03^{* 1}$ & $1,11 \pm 0,02^{* 1}$ \\
\hline 6 & КАн & - & $1,6 \pm 0,05$ & $1,1 \pm 0,04^{* 1}$ & $1,05 \pm 0,03^{* 1}$ & $1,1 \pm 0,06^{* 1}$ \\
\hline 7 & $\Phi Ч$ & абс. & $2,8 \pm 0,1$ & $1,9 \pm 0,3^{* 1}$ & $2,1 \pm 0,1^{* 1}$ & $2,4 \pm 0,2^{* 1}$ \\
\hline 8 & $\Phi \Pi$ & $\%$ & $77,2 \pm 1,6$ & $34,3 \pm 0,9^{* 1}$ & $35,4 \pm 2,7^{* 1}$ & $45,0 \pm 3,4^{* 1-3}$ \\
\hline 9 & ИАФ & - & $2,2 \pm 0,09$ & $0,7 \pm 0,1^{* 1}$ & $0,74 \pm 0,04^{* 1}$ & $1,1 \pm 0,02^{* 1-3}$ \\
\hline
\end{tabular}

Так как максимально выраженные изменения функционально-метаболической активности (ФМА) циркулирующих нейтрофилов наблюдались при ХАИ-30, ХАИ-60 без и в комбинации с моделью
ОДП, актуальной явилась разработка подходов фармакологической коррекции на примере данных экспериментальных групп.

Сочетание гепона, гипоксена и фосфоглива при ОДП на фоне ХАИ-30 корректи- 
ровало, не достигая нормального уровня ФП, ФЧ, ИАФ, НСТ-сп., НСТ-ст. о/з и н/3, в еще более выраженной степени снижало функциональные резервы КО, КАн. Введение животным с моделью ОДП при ХАИ-30 комплекса глутоксим, мексидол и гептрал нормализовало ФЧ, НСТ-ст. о/3 и н/3, КАн, КО и корректировало, но не достигая уровня нормы ФП, ИАФ, НСТ-сп., КАо (табл. 3).

Сочетание гепон, гипоксен и фосфоглив у крыс с ОДП при ХАИ-60 не привело к изменениям всех показателей ФМА нейтрофилов, по сравнению с группой животных без коррекции. При экспериментальном ОДП на ХАИ-60 применение комбинации глутоксим, мексидол и гептрал корригировало фагоцитарную активность полиморфноядерных лейкоцитов, НСТ-сп. и НСТ-ст. о/3 и н/3, но не влияло на сниженные ФЧ, КАо, КО, Кан (табл. 3).

При ХАИ-30 выявлена стимуляция ГЗТ, при отсутствии изменений со стороны ГИО на ЭБ. При 60-дневном введении этанола установлена супрессия формирования и клеточной и гуморальной форм иммунного ответа, о чем свидетельствовало снижение иммунных АОК в селезенке, а также РМ и РК. При экспериментальном деструктивном панкреатите в условиях ХАИ-30, в большей степени при ХАИ- 60 , установлено по сравнению с контролем и животными, получавшими только этанол, выраженное ингибирование ГИО и ГЗТ на ЭБ.

Введение комплекса препаратов гипоксен, гепон и фосфоглив животным с ОДП в сочетании с 30-дневной ХАИ корректировало, но не достигая нормы, формирование адаптивного иммунитета. Использование сочетания глутоксима, мексидола и гептрала нормализовало число иммунных АОК в селезенке экспериментальных животных, корригировало, но до контрольной группы РМ и РК.

Использование гепона, гипоксена и фосфоглива в условиях ОДП и ХАИ-60 ча- стично корригировало показатель ГИО (иммунные АОК в селезенке), но не влияло на параметры ГЗТ (РМ и РК лимфатических подколенных узлов). Применение глутоксима, мексидола и гептрала корригировало как уровень иммунных АОК, так и РМ, РК, но не до параметров здоровых животных.

Таким образом, при остром панкреатите, формирующемся при длительном воздействии спирта этилового, наиболее предпочтительной является комбинированная фармакологическая терапия, позволяющая влиять на несколько патогенетических звеньев одновременно.

Фармакологическая коррекция оксидантного стресса и метаболических эритроцитарных нарушений в условиях длительного введения этанола и экспериментального острого панкреатита. Установлено, что у животных с 5-кратным введением этанола оказалось увеличенным только содержание АГП, а у крыс с ОДП на фоне кратковременной алкогольной интоксикации выявлено повышение содержания продуктов ПОЛ (МДА и АГП), снижение уровня $\mathrm{CM}_{\mathrm{NO}}$ и активности СОД.

В условиях ХАИ-30 повышена концентрация МДА, АГП, активность каталазы, при одновременном снижении СОД и уровня $\mathrm{CM}_{\mathrm{NO}}$. Моделирование ОДП в этих условиях привело к более выраженному количественному повышению продуктов ПОЛ, снижению уровня $\mathrm{CM}_{\mathrm{NO}}$, и факторов антиоксидантной защиты (за исключением активности каталазы) (рис. 2). Поступление этанола в течение 60 суток, по сравнению с его 30-дневным введением, увеличивало уровень МДА, АГП, $\mathrm{CM}_{\mathrm{NO}}$ и снижало активность каталазы. При ОДП при 60дневной хронической интоксикации этанолом наблюдалось развитие более выраженного по исследованным лабораторным параметрам «окислительного стресса» и снижение уровня $\mathrm{CM}_{\mathrm{NO}}$ (рис. 2). 


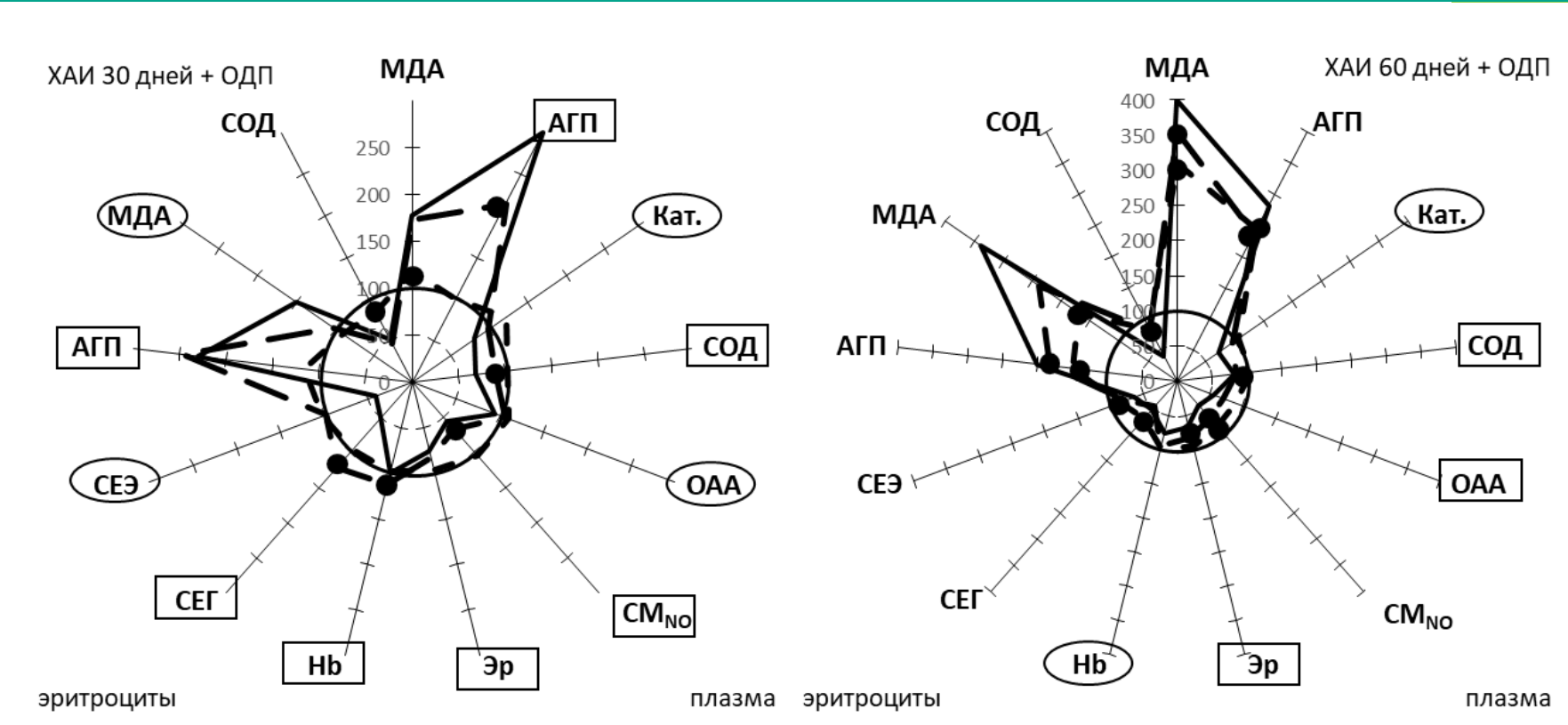

Обозначения:

1 - радиус окружности показатели интактных животных;

2 - — - показатели крыс с 30- и 60-дневной ХАИ + ОДП;

3 - _ - - - показатели крыс с 30- и 60-дневной ХАИ + ОДП + гепон, гипоксен и фосфоглив;

4 - - - - - показатели крыс с 30- и 60-дневной ХАИ + ОДП + глутоксим, мексидол и гептрал;

5 - - скорригированный показатель ( $<<0,05)$;

$6-\circlearrowright-$ показатель, нормализованный сочетанием гепон, гипоксен, фосфоглив $(\mathrm{p}>0,05)$;

7 - $\square$ - показатель, нормализованный сочетанием глутоксим, мексидол, гептрал (р>0,05).

Legend:

1 - radius of a circle indicators of intact animals;

$2-\ldots-$ indicators of rats with 30- and 60-day HAI + CCT;

$3-\ldots--$ indicators of rats with 30- and 60-day HAI + ODP + gepon, hypoxen and phosphogliv;

$4-$ - - - - indicators of rats with 30- and 60-day HAI + ODP + glutoxim, mexidol and heptral;

5 - $\quad-$ corrected indicator $(\mathrm{p}<0.05)$;

$6-\bigcirc-$ indicator, normalized by the combination of gepon, hypoxen, phosphoglive (p>0.05);

$7-\square-$ indicator normalized by the combination of glutoxim, mexidol, heptral ( $\mathrm{p}>0.05)$.

Рис. 2. Коррекция нарушений функциональной активности гепатоцитов при ОДП у крыс на фоне 30- и 60-дневного введения этанола

Fig. 2. Correction of impaired functional activity of hepatocytes in simulation of acute destructive pancreatitis in rats on the background of 30 and 60 days of ethanol injection

При ОДП в условиях ХАИ-30 одновременное введение гипоксена, гепона и фосфоглива приближало статистически достоверно, но не достигая значений здоровых животных, концентрацию АГП, $\mathrm{CM}_{\mathrm{NO}}$, активность СОД и нормализовало ОАА и активность каталазы. Введение мексидола, глутоксима и гептрала в данных условиях корректировало ОАА, содержание МДА и активность каталазы, нормализовало активность СОД, концентрацию АГП и $\mathrm{CM}_{\mathrm{NO}}$ (рис. 2).

При 60-дневной интоксикации этиловым спиртом и моделировании ОДП применение фосфоглива, гипоксена и гепона нормализует активность каталазы и корректирует, но не достигая значений интактных животных, концентрацию продуктов ПОЛ 
(МДА, АГП), стабильных метаболитов оксида азота $\left(\mathrm{CM}_{\mathrm{NO}}\right)$ и активность СОД. Введение гептрала, глутоксима и мексидола в этих же условиях уменьшает в сторону контрольных животных, но не до их уровня, показатели ПОЛ и содержание $\mathrm{CM}_{\mathrm{NO}}$, нормализует ОАА, активность СОД и каталазы (рис. 2).

Далее нами изучены показатели метаболической активности циркулирующих эритроцитов. Выявлено, что кратковременное введение этанола снижает общее их количество красных кровяных клеток, активность в них СОД и сорбционные показатели (ССЭ и СЭГ). На этом фоне моделирование ОДП активирует процессы ПОЛ (повышение концентрации АГП и МДА), приводит к более выраженному снижению активности СОД и параметров сорбционной способности эритроцитов (ССЭ) (рис. 2).

При ХАИ-30 и ХАИ-60, по сравнению c 5-дневной интоксикацией, установлено выраженное развитие внутриэритроцитарного оксидантного стресса (повышение продуктов ПОЛ с одновременным снижением факторов антиоксидантной защиты), снижение количества эритроцитов, причем более выражены эти явления при ХАИ-60. Следует отметить, что выявлена различная динамика сорбционных свойств эритроцитов: на фоне ХАИ-30 увеличено ССЭ и СЕГ, а при ХАИ-60 данные показатели снижены, причем ССЭ ниже значений контрольной группы (рис. 2).

Моделирование ОДП при 30-дневной интоксикации этанолом, по сравнению с введением только этанола, оказалось более выражено в количественном отношении, внутриэритроцитарного развития оксидантного стресса с разнонаправленными изменениями сорбционных показателей мембраны эритроцитов. ОДП при ХАИ-60 приводит к более явному, по сравнению с введеним в течение 2 месяцев только спирта, снижению СЕГ, количества эритроцитов, гемоглобина в них, повышению ССЭ и концентрации МДА (рис. 2).

Применение в условиях ОДП в режиме 30-суточного введения этанола комбинации фосфоглива, гипоксена и гепона повышает содержание гемоглобина (Hb) и СЕГ, нормализует ССЭ и уровень МДА. Введение в этих условиях мексидола, гептрала и глутоксима корригирует активность СОД, но не до уровня здоровых крыс, нормализует сорбционные показатели мембраны клеток, общее их количество и внутриклеточную концентрацию продуктов ПОЛ (АГП и МДА) (рис. 2).

Введение при ОДП на фоне 60дневной интоксикации этанолом комплекса фосфоглив, гепон и гипоксен корректирует в сторону нормы содержание эритроцитов, АГП, активность СОД и нормализует количество $\mathrm{Hb}$, , не влияя на концентрацию МДА в эритроцитах и сорбционные параметры мембраны клеток. Использование в этих условиях мексидола, гептрала и глутоксима нормализует количество эритроцитов и содержание в них гемоглобина, приближает, но не до значений здоровых животных, остальные исследованные показатели метаболизма циркулирующих эритроцитов (рис. 2).

О развитии ОС в условиях ОДП, лабораторные признаки которого усиливаются в условиях ХАИ, свидетельствует повышение в плазме крови и эритроцитах концентрации продуктов ПОЛ (АГП и МДА) и снижение параметров антиоксидантной защиты (OAA, активности СОД и каталазы) $[19,20]$.

Применение препаратов с иммуномодулирующими, антиоксидантными и гепатопротекторными эффектами оказывает выраженный положительный эффект в частичном купировании ОС и нарушении метаболизма эритроцитов.

Сравнительная корригирующая эффективность различных методов фармакологической коррекции метаболических и иммунных нарушений при длительном введении этанола и экспериментальном остром панкреатите. Применение двух различных сочетаний, включающих иммуномодуляторы, гепатопротекторы и антиоксиданты, для коррекции иммунометаболических патологических изменений при ОДП на фоне длительного введения этанола, закономерно поставило вопрос об их сравнительной эффективности.

Первоначально проведено количественное и качественное сравнение измене- 
ний иммунометаболических параметров при введении только этанола в течение 5, 30 и 60 дней и в условиях ОДП на фоне кратковременной и длительной алкоголизации.

При количественном сравнении нарушенных показателей в разных условиях эксперимента с делением глубины изменений по степеням установлено, что при введении спирта этилового в течение 5 суток нарушенными из 24 лабораторных показателя оказались 10 (41,7\%), из которых 2-3 степени всего 4 (16,7\%). Этанольная интоксикация в течение 30 или 60 суток соответственно приводит к изменению 27 из $34(79,4 \%)$ и $29(85,3 \%)$ показателей с выраженным увеличением нарушений 2-3 степени: соответственно $38,3 \%$ и $50 \%$. Сочетание принудительного введения спирта и ОДП по сравнению с поступлением только этанола изменяет большинство показателей в сторону 2-3 степени. Так, при 5- дневной интоксикации этанолом и ОДП это 87,5\% параметоров, из них 2-3 степени 66,7\%, при ОДП на фоне ХАИ-30 и ХАИ-60 соответственно - 97,1\% и $100 \%$, а глубокие нарушения $-61,8 \%$ и $76,4 \%$.

Была проведена сравнительная эффективность различных комбинаций иммуномодуляторов, антиоксидантов и мембранопротекторов при моделировании ОДП на фоне 30 - и 60-дневной этанольной интоксикации.

У крыс с ОДП при ХАИ в разной степени были нарушены 97,1\% изученных лабораторных показателей, характеризующих функциональную активность гепатоцитов, клеточную и гуморальную формы адаптивного иммунитета, ПОЛ, антиоксидантную защиту, функциональнометаболическую активность нейтрофилов и эритроцитов периферической крови. Введение гепона, гипоксена и фосфоглива нормализовало $\quad 12,1 \%$ измененных показателей, корректировало $60,6 \%$ и не оказывало влияния на 27,3\%. Комбинация глутоксима, мексидола и гептрала оказалась наиболее эффективной, так как нормализовала $57,8 \%$.
При качественном сопоставлении числа нарушенных исследованных иммунологических параметров выявлено, что при ОДП при ХАИ-30 без коррекции измененными от значений нормы было 97,1\% исследованных показателей, при этом выявлено, что I степень нарушений имели $35.3 \%$, а II и III соответственно - 26,5\% и 35,3\%. После коррекции, включавшей гепон, гипоксен и фосфоглив, измененными оказалось $87,9 \%$ параметров, а соответственно I, II и III степень нарушений имели $51,5 \%, 9,1 \%$ и $27,3 \%$. После использования глутоксима, мексидола и гептрала нарушенными осталось 42,4\% показателей (соответственно I, II и III степень нарушений была у $33,3 \%, 3 \%$ и $6,1 \%$ (табл. 4).

При ОДП при интоксикации этанолом в течение 60 суток оказались нарушенными $100 \%$ лабораторных показателей. Комбинация глутоксима, мексидола и гептрала оказалась наиболее эффективной, так как нормализовала 17,6\%, корректировала $67,6 \%$ и не влияла на $14,7 \%$ исследованных параметров.

Следует отметить, что при ОДП на фоне ХАИ-30 в наименьшей степени подлежали коррекции параметры функционально-метаболической активности эритроцитов, то при ХАИ-60 - иммунные показатели.

При анализе качественных изменений установлено, что при ОДП на фоне ХАИ-60 без введения препаратов измененными от значений нормы было 100\% исследованных показателей, при этом I степень нарушений имели $23,5 \%$, а II и III соответственно по $38,2 \%$. После использования гепона, гипоксена и фосфоглива, измененными оказалось $88,2 \%$ параметров иммунного статуса, а соответственно I, II и III степень нарушений имели $23,5 \%, 32,4 \%$ и $32,4 \%$. После использования глутоксима, мексидола и гептрала нарушенными осталось 79,4\% показателей (соответственно I, II по 29,4\%, а III степень $18,9 \%$. 
Сравнительная иммунометаболическая эффективность различных схем

Таблица 4 фармакологической коррекции при ОДП на фоне длительной алкогольной интоксикации

Table 4

Comparative immunometabolic efficacy of various pharmacological correction regimens in case of ADP on the background of prolonged alcohol intoxication

\begin{tabular}{|c|c|c|c|c|c|c|c|c|c|}
\hline \multirow{3}{*}{$\Pi / \Pi$} & \multirow{3}{*}{ Условия исследования } & \multirow{2}{*}{\multicolumn{2}{|c|}{$\begin{array}{c}\text { Измененные } \\
\text { показатели от } \\
\text { значений здо- } \\
\text { ровых живот- } \\
\text { ных }\end{array}$}} & \multicolumn{6}{|c|}{$\begin{array}{c}\text { Измененные показатели по степени } \\
\text { расстройств }\end{array}$} \\
\hline & & & & \multicolumn{2}{|c|}{ I } & \multicolumn{2}{|c|}{ II } & \multicolumn{2}{|c|}{ III } \\
\hline & & абс. & $\%$ & абс. & $\%$ & абс. & $\%$ & абс. & $\%$ \\
\hline \multicolumn{10}{|c|}{ 30-дневная алкогольная интоксикация } \\
\hline 1 & Без введения препаратов & 33 & 97,1 & 12 & 35,3 & 9 & 26,5 & 12 & 35,3 \\
\hline 2 & $\begin{array}{l}\text { Введение фосфоглива, ге- } \\
\text { пона и гипоксена }\end{array}$ & 29 & 87,9 & 17 & 51,5 & 3 & 9,1 & 9 & 27,3 \\
\hline 3 & $\begin{array}{l}\text { Введение мексидола, глу- } \\
\text { токсима и гептрала }\end{array}$ & 14 & 42,4 & 11 & 33,3 & 1 & 3 & 2 & 6,1 \\
\hline \multicolumn{10}{|c|}{ 60-дневная алкогольная интоксикация } \\
\hline 1 & Без введения препаратов & 34 & 100 & 8 & 23,5 & 13 & 38,2 & 13 & 38,2 \\
\hline 2 & $\begin{array}{l}\text { Введение фосфоглива, ге- } \\
\text { пона и гипоксена }\end{array}$ & 30 & 88,2 & 8 & 23,5 & 11 & 32,4 & 11 & 32,4 \\
\hline 3 & $\begin{array}{l}\text { Введение мексидола, глу- } \\
\text { токсима и гептрала }\end{array}$ & 27 & 79,4 & 10 & 29,4 & 10 & 29,4 & 7 & 18,9 \\
\hline
\end{tabular}

Результаты оценки собственных корригирующих эффектов антиоксидантов, гепатопротекторов и иммуномодуляторов при ОДП на фоне ХАИ представлены в таблице 5.

Таблица 5

Собственные корригирующие эффекты различных сочетаний иммуномодуляторов, антиоксидантов и гепатопротекторов при ОДП на фоне ХАИ

Table 5

Own corrective effects of various combinations of immunomodulators, antioxidants and hepatoprotectors in case of ADP on the background of chronic toxicity with ethanol

\begin{tabular}{|l|l|l|}
\hline$№$ п\} $&{\text { Схемы фармакологического лечения }} &{\text { Сумма показателей коррекции }} \\
{\hline 1} &{\multicolumn{2}{|c|}{\text { ОДП на фоне ХАИ-30 }}\text { ОДП на фоне ХАИ-30 }} \\
{\hline 2} &{\text { Гипоксен, фосфоглив и гепон }} &{46} \\
{\hline 3} &{\text { Мексидол, гептрал и глутоксим }} &{84} \\
{\hline 4} &{\multicolumn{2}{|c|}{\text { ОДП на фоне ХАИ-60 }}\text { ОДП на фоне ХАИ-60 }} \\
{\hline 5} &{\text { Гипоксен, фосфоглив и гепон }} &{15} \\
{\hline 6} &{\text { Мексидол, гептрал и глутоксим }} &{37} \\
{\hline}$
\end{tabular}

По иммунологической и метаболической эффективности при ОДП на фоне ХАИ-30 сочетание гептрал, глутоксим, мексидол (84 балла) оказалась более предпочтительней чем фосфоглив, гепон, гипоксен (46 баллов).
При ХАИ-60 по иммунометаболической эффективности композиция мексидол, гептрал и глутоксим (37 баллов) оказалась также эффективнее сочетания гипоксен, фосфоглив и гепон (15 баллов).

Таким образом, использование различных статистических методов позволяет 
утверждать, что в условиях ОДП на фоне ХАИ более эффективней оказалось сочетание глутоксим, мексидол и гептрал по сравнению с гепоном, гипоксеном и фосфогливом.

Заключение. Кратковременная интоксикация спиртом этиловым вызывает метаболические изменениям реактивного характера, 30-дневное и 60-дневное его введение, ведет к формированию токсического повреждения печени, окислительному стрессу, дисбалансу формирования адаптивного и врожденного иммунного ответа, нарушениям функционально-метаболической активности циркулирующих эритроцитов. При остром деструктивном панкреатите у крыс на фоне алкогольной интоксикации установлено более выраженное развитие цитолитического синдрома, внутриклеточного холестаза, токсического поражения печени, активация свертывающей системы крови.

При оценке собственных корригирующих фармакологических эффектов при остром деструктивном панкреатите на фоне 30- и 60-дневной алкогольной интоксикации сочетание гептрала, глутоксима и мексидола (соответственно 84 и 37 баллов) оказалась более предпочтительней чем фосфоглива, гипоксена и гепона (соответственно 46 и 15 баллов).

\section{В отнотении данной статьи не было зарегистрировано конфликта интересов.}

\section{Список литературы}

1. Дунаевская С.С. Хронический рецидивирующий панкреатит с образованием кальцинатов и петрификатов поджелудочной железы как исход острого алкогольного панкреатита // Кубанский научный медицинский вестник. 2013. T. 138, № 3. С. 57-58.

2. Халютин Д.А. Терапевтический эффект новых нейропептидов и гепатопротектора моликсан при острых отравлениях этанолом // Токсикологический вестник. 2015. №2(131). C. 10-17.

3. Винник Ю.С. Риск развития осложнений при остром алкоголь-ассоциированном панкреатите // Новости хирургии. 2012. Т.20, №4. C. $38-41$.

4. Конопля А.И. Взаимосвязь иммунометаболических и эритроцитарных нарушений с этиологией острого панкреатита. Курск: Изд-во
ГОУ ВПО КГМУ Минздрава России, 2013. $162 \mathrm{c}$.

5. Мхитаров В.Л. Влияние длительного принудительного потребления алкоголя на иммунную систему самцов крыс Вистар, предпочитающих и не предпочитающих алкоголь // Медицинская иммунология. 2015. Т. 17, №S. C. 49 .

6. Pathophysiological mechanisms of acute pancreatitis define inflam-matory markers of clinical prognosis / G.A. Minkov [et al.] // Pancreas. 2015. Vol.44, №5. P. 713-717.

7. Особенности регуляции апоптоза иммунокомпетентных клеток крови при остром деструктивном панкреатите / Ю.С. Винник [и др.] // Новости хирургии. 2011. Т.19, №2. C. $37-42$.

8. Показатели иммунного и оксидантного статуса при диагностике острого панкреатита билиарной и небилиарной этиологии / О.А. Суняйкина [и др.] // Медицинская иммунология. 2015. Т.17, №4. С. 381-382.

9. The predominance of a naive $\mathrm{T}$ helper cell subset in the immune response of experimental acute pancreatitis / A.I. Schmidt [et al.] // Pancreatology. 2017. Vol. 17, №2. P. 209-218.

10.Горский В.А. Синдром системной воспалительной реакции и возможный путь коррекции при остром панкреатите // Врач. 2014. №7. C. 47-49.

11.Караулов А.В. Иммунология, микробиология, иммунопатология кожи. Москва: Бином, 2012. $328 \mathrm{c}$.

12.Иммуномодуляторы, антиоксиданты, гепатопротекторы в коррекции иммунометаболических нарушений при экспериментальном деструктивном остром панкреатите в условиях хронической алкогольной интоксикации / А.И. Конопля [и др.] // Научные ведомости Белгородского государственного университета. Серия: Медицина. Фармация. 2015. №16 (213). C. 141-148.

13.Effects of Tocilizumab on Experimental Severe Acute Pancreatitis and Associated Acute Lung Injury / K.L. Chen [et al.] // Crit Care Med. 2016. Vol. 44, №8. e664-677.

14.Экспериментальная модель панкреонекроза / В.А. Горский [и др.] // Анналы хирургической гепатологии. 2014. Т.19, №1. C. 103-109.

15.Дифференциальная лабораторная диагностика острого билиарного и небилиарного панкреатита / А.Л. Локтионов [и др.] // Научные ведомости БелГУ. Сер.: «Медицина. Фармация». 2015. №16, (213). Вып. 31. С. 31-39. 
16.Морфологические особенности действия пептидных препаратов при остром отравлении этиловым спиртом в эксперименте / Д.А. Халютин [и др.] // Токсикологический вестник. 2015. Т. 133, №4. С. 31-37.

17.Indoleamine 2,3-dioxygenase is upregulated in the brain of rats with acute pancreatitis / H. Jiang [et al.] // Pancreatology. 2015. Vol. 15, №3. P. 281-285.

18.Зинкин В.Ю. Способ оценки кислородзависимого метаболизма нейтрофильных гранулоцитов человека // Клиническая и лабораторная диагностика. 2004. № 2. С. 27-31.

19.Земсков А.М. Клиническая эффективность применения иммунотропных препаратов при гнойных инфекциях // Хирургия. 2011. № 2. C. $4-10$.

20.Коррекция метаболической активности эритроцитов периферической крови при экспериментальном остром токсическом поражении печени / М.С. Разумова [и др.] // Современные проблемы науки и образования. 2016. № 5. C. 51.

\section{References}

1. Dunaevskaya SS. [Chronic recurrent pancreatitis with the formation of calcifications and petrification of the pancreas as an outcome of acute alcoholic pancreatitis]. Kuban Scientific Medical Bulletin. 2013;138(3):57-58. Russian.

2. Khalyutin DA. [Therapeutic effect of new neuropeptides and hepatoprotector moliksan in acute poisoning with ethanol]. Toxikologicheskii vestnik. 2015;2(131): 10-17. Russian.

3. Vinnik YS. [Risk of complications in acute alcohol-associated pancreatitis]. Novosti Khirurgii. 2012;20(4):38-41. Russian.

4. Konoplya AI. The relationship of immunometabolic and erythrocyte disorders with the etiology of acute pancreatitis. Kursk: Publishing house GOU VPO KGMU Minzdrava Rossii; 2013.

5. Mkhitarov VL. [The influence of longterm forced alcohol consumption on the immune system of male Wistar rats, who prefer and do not prefer alcohol]. Medical immunology. 2015;17(S):49. Russian.

6. Minkov GA, Halacheva KS, Yovtchev YP, et al. Pathophysiological mechanisms of acute pancreatitis define inflammatory markers of clinical prognosis. Pancreas. 2015;44(5):713-717.

7. Vinnik YS, Cherdancev DV, Salmina AB, et al. [Features of regulation of apoptosis of immunocompetent blood cells in acute destructive pancreatitis]. Novosti Khirurgii. 2011;19(2):37-42. Russian.
8. Suinyakina OA, Konoplya AI, Loktionov $\mathrm{AL}$, et al. [Indicators of immune and oxidative status in the diagnosis of acute pancreatitis of biliary and non-biliary etiology]. Medical immunology. 2015;17(4):381-382. Russian.

9. Schmidt AI, Kühlbrey C, Lauch R, et al. The predominance of a naive $\mathrm{T}$ helper cell subset in the immune response of experimental acute pancreatitis. Pancreatology. 2017;17(2):209-218.

10. Gorsky VA. [Systemic inflammatory reaction syndrome and a possible way of correction in acute pancreatitis]. Vrach. 2014;7:47-49.

11. Karaulov AV. Immunology, Microbiology, immunopathology of the skin. Moscow: Binom; 2012.

12. Konoplya AI, Bushmina ON, Loktionova $\mathrm{AV}$, et al. [Immunomodulators, antioxidants, membrane protectors in the correction of immunometabolic disturbances in experimental destructive acute pancreatitis in conditions of chronic alcoholic intoxication]. Scientific Bulletin of Belgorod State University. Series: Medicine. Pharmacy. 2015;16(213):141-148. Russian.

13. Chen KL. Effects of Tocilizumab on Experimental Severe Acute Pancreatitis and Associated Acute Lung Injury. Crit Care Med. 2016;44(8):e664-677.

14. Gorsky VA, Agapov MA, Leonenko IV, et al. [Experimental Model of Pancreonecrosis]. Annaly Khirurgicheskoi Gepatologii. 2014;19(1):103-109. Russian.

15. Loktionov AL, Kozlova AI, Voropaev $\mathrm{EV}$, et al. [Differential laboratory diagnostics of acute biliarny and nonbiliarny pancreatitis]. Scientific Bulletin of Belgorod State University. Series: Medicine. Pharmacy. 2015;16(213). Iss. 31:31-39. Russian.

16. Halutin DA. [Morphological features of action of peptide preparations in acute poisoning with ethyl alcohol in experiment]. Toksicologicheskii vestnik. 2015;133(4):31-37. Russian.

17. Jiang $\mathrm{H}$, Li F, Liu S, et al. Indoleamine 2,3-dioxygenase is upregulated in the brain of rats with acute pancreatitis. Pancreatology. 2015;15(3):281-285.

18. Zinkin VU. [Method of assessment kislorodozavisimogo metabolism of neutrophils human]. Klinicheskaia i laboratornaia diagnostika. 2004;2:27-31. Russian.

19. Zemskov AM. [Clinical efficacy of immune modulating drugs in septic infections]. Khirurgia. 2011;2:4-10. Russian.

20. Razumova MS, Litvinova ES, Bystrova NA, et al. [Correction of the metabolic activity of peripheral blood erythrocytes in experimental acute liver toxicity]. Modern problems of science and education. 2016;5:51. Russian. 
Информация об авторах

Ольга Николаевна Бушмина, ассистент кафедры биологической химии ФГБОУ ВО «Курский государственный медицинский университет». E-mail: o.buschmina@yandex.ru.

Алексей Леонидович Локтионов, доктор медицинских наук, доцент, профессор кафедры хирургических болезней №2 ФГБОУ ВО «Курский государственный медицинский университет». E-mail: ala-loc@yandex.ru, ORCID: 00000003-4833-1581.

Светлана Анатольевна Долгарева, доктор медицинских наук, доцент, профессор кафедры биологической химии ФГБОУ ВО «Курский государственный медицинский университет». E-mail: dolgareva-svetlana@ rambler.ru.

Александр Иванович Конопля, доктор медицинских наук, профессор, заслуженный деятель науки РФ, заведующий кафедрой биологической химии ФГБОУ ВО «Курский государственный медицинский университет». E-mail: konoplya51@ mail.ru.
Information about the authors

Olga N. Bushmina, Assistance Lecturer of the Department of Biological Chemistry, Kursk State Medical University. E-mail: o.buschmina@yandex.ru.

Alexey L. Loktionov, Doctor of Medical Sciences, Associate Professor, Professor of the Department of Surgical Diseases №2, Kursk State Medical University. E-mail: ala-loc@yandex.ru, ORCID: 00000003-4833-1581.

Svetlana A. Dolgareva, Doctor of Medical Sciences, Associate Professor, Professor of the Department of biological chemistry, Kursk State Medical University. E-mail: dolgareva-svetlana@ rambler.ru. Alexandr I. Konoplya, Doctor of Medical Sciences, Professor, Honored Worker of Science of the Russian Federation, Head of the Department of Biological Chemistry, Kursk State Medical University. E-mail: konoplya51@mail.ru.

Статья поступила в редакцию 8 июля 2018 г. Receipt date 2018 July 8.

Статья принята к публикации 25 сентября 2018 г. Accepted for publication 2018 September 25. 